\title{
Blended Learning in Rural Primary ESL Classroom: Do or Don't
}

\author{
Melanie Jerry \\ Sekolah Kebangsaan Dit, Debak, Sarawak \\ http:/ / orcid.org/0000-0002-6960-5994 \\ Melor Md Yunus \\ Universiti Kebangsaan Malaysia, Bangi, Selangor \\ http://orcid.org/0000-0001-7504-7143
}

\begin{abstract}
The emergence of the Fourth Industrial Revolution (4IR) had led to discussions of the constructive relationship between the integration of technology and teaching and learning to meet society's needs in the innovative era. However, despite the current technology advancement, rural schools' circumstances propelled teachers to shy away from integrating technology in their instruction. Therefore, this paper presented a research to examine primary school teachers' experiences and views on the application of blended learning in their English language instruction using a mixed-method explanatory design. A survey questionnaire was employed to collect data from 86 teachers from schools in the Betong district, while a semi-structured interview was designed and done with five teachers. Data from the questionnaire were analysed descriptively, while the interview was analysed thematically. The results illustrated that teachers lacked exposure and adequate knowledge of blended learning. It was deduced that teachers had mixed reactions towards blended learning, varying based on their experiences. Teachers emphasised that the lack of facilities and technological constraints, time, limited exposure and skills in ICT use, and teacher readiness were the main challenges they encountered. This study may serve as a building block towards the broad dissemination of blended learning among teachers and serious consideration and effective solutions for the problems faced in its adoption, particularly in rural schools.
\end{abstract}

Keywords: blended learning; English teaching and learning; educational technology; teachers experiences; Integration of technology

\section{Introduction}

Recently, due to the COVID-19 pandemic outbreak, "the global disruption of pre-existing curriculum resulted in the reinvention of educational practices aimed at minimising the learning losses" (Polushkina \& Tareva, 2021, p. 38). 
Such a fact could be witnessed across nations, and the Malaysian context is not an exception. Accordingly, the Malaysian government had taken the measure to pose Movement Control Order (MCO) throughout the country, which affected society's norms, including the schooling period. During MCO's duration, teachers across Malaysia were instructed to conduct online classes with their students using Google Classroom or any digital modalities accessible and convenient for both the teachers and students. This led to the discussions over how online learning can be optimised primarily when it pertains to those in the rural demographic setting. As Fitriani et al. (2021) said, teachers and students may enjoy the benefits and face the challenges imposed by online teaching and learning activities.

The merge of traditional face-to-face interaction with technology-mediated learning known as blended learning conveyed the impression of an ideal approach for education in the current digitally governed world. As elucidated by Kim (2007), both traditional and online instruction's strengths and flaws can be regulated by combining the potentials of the two into blended learning. In the same vein, Hariharasudan and Kot (2018) corroborated the constructive relationship between the integration of technology and teaching and learning to meet society's needs in the innovative era. The dynamics of blended learning should cater to the ever-changing perspectives on how a modern classroom should serve as a learning space and what it can offer. The incorporation of technology in the myriad scope of education, including English language learning, conveyed the impression that it could be a catalyst to an effective education system in the debate of preparing our youth for the demands of the future world. Razali (2016) stated that evolving technologies had a major influence on educational development.

Despite the initiatives taken by the Malaysian Ministry of Education (MoE) to facilitate English language teaching and learning in the country, there is a minimal significant effect on students' proficiency, particularly in rural schools. English is commonly viewed as a difficult subject by students in this context, which can be observed based on their classroom performances and assessments. Undoubtedly, the English curriculum revision had considered students of diverse learning settings (urban, suburban and rural) and allowed teachers to adopt and adapt their lessons accordingly. However, inevitable issues and concerns such as inadequate facilities and infrastructure, limited digital accessibility, unfitting learning materials and resources, and insufficient technological knowledge and skills in both educators and learners were in existence.

Studies on blended learning in the context of tertiary education were widely explored, but there is a need to widen the research in the context of primary levels of education, as well as in English as a Second Language (ESL) setting, particularly in rural schools in Malaysia. Therefore, the constructs in this research explored teachers' experiences in implementing blended learning in terms of its influences, successes and challenges. Administrators and other decision-makers would strategize implementation protocols that augmented 
optimistic teacher expectations and blended learning pedagogy implementation through learning about their perspectives on the approach's essence in their teaching (Raymond, 2019). This is in line with the researcher's objective to observe the deliberation of blended learning as an avenue for the teaching and learning of English in rural classrooms based on these experiences. From there, a prospect to educate teachers, including other chief stakeholders, on the approach can be initiated to optimise English language instruction effectiveness.

\section{Literature Review}

\subsection{Technology Acceptance Model}

Access did not necessarily instigate utilisation (Murphy, 2019). The TAM (technology acceptance model) was used in this research to see whether elementary school teachers were adamant about incorporating blended learning (BL). TAM was created by Davis (1989) as a more accurate method of forecasting technology acceptance and use. The original model had two key constructs: perceived ease of use (PEU) and perceived utility (PU), which were used to predict an individual's behavioural intention to implement technology, which ultimately contributed to actual use. As discovered by Al-Azawei, Parslow and Lundquist (2017), the influences on PEU and PU may indicate the indirect impact on perceived satisfaction (PS) and intention to use (ITU). Based on this, TAM was used to examine whether teachers perceived blended learning as a relevant and useful instructional strategy and review how difficult it is to develop blended learning opportunities. The aim of this study was to look at the perspectives, causes, and challenges that primary school teachers face while using blended learning instructional methods. To meet these aims, computer self-efficacy, prior online learning experience, and teaching beliefs were the three variables in correspondence to TAM constructs to gather information on teacher's perceptions based on their experiences, factors and challenges posed.

\subsection{Teacher Perceptions of Blended Learning}

Teacher acceptance could be defined as the teacher's willingness to explore and understand how a contemporary method, strategy or technique fits best for the betterment of their teaching and learning. It could reflect their knowledge and skills advancement in the subject matter, to develop professionally and become true teachers of current times. Teacher acceptance is an important element for the adoption of emerging technological tools and innovations. Thus, research into which variables influenced the technology perspectives of teachers leading to their intention to use them or not to use them was significant (Murphy 2019). This implies that teacher acceptance can be determined based on the diverse features of BL that could either increase or hamper their inclination to adopt and use the approach. Gough et al. (2017) supported the notion of teacher acceptance as they believed that teachers' satisfaction and acceptance of emerging technologies, processes, and how they fit into their teaching were imperative for acceptance and subsequent usage.

\subsection{Influences and Successes of Blended Learning}

Sorbie (2015) outlined teachers' perceptions towards the approach, which indicated a direct relationship between the influences of blended learning on 
teaching and learning and the successes of its implementation. As teachers became aware of the potential of blended learning in elevating teaching practice and instruction, they could see the relevance in adopting and aligning the approach in suitable ways for their curriculum and students. In this line of thought, it should be noted that becoming aware of a pedagogical need for change is the first step in the blended learning implementation process (Bruggeman et al., 2021). Because teachers had the first-hand contact with students as the front liners in the education setting and the main implementers of educational policies, thus, it was crucial that teachers took proactive measures to be well-informed of the educational transformations to ensure that their teaching styles stayed relevant and they continued to develop professionally. With adequate knowledge and skills, they would be able to guide students and build competent individuals who could thrive through the era of digitalisation. The need to improve the acquisition of blended knowledge and digital skills by teachers was associated with the provision of quality education and the promotion of versatility for teachers (Jachin \& Usagawa, 2017). Ultimately, teaching values had a strong impact on the educational decisions of the teacher.

Cleveland-Innes and Wilton (2018) described blended learning as a platform for instruction and learning experiences by merging traditional face-to-face and online learning. In the blended approach, a teacher took on the role of a facilitator as students were expected to direct the pace and timing of their learning. This is in line with the current CEFR-aligned English language curriculum, whereby student autonomy in learning was emphasised. Padmadewi, Artini \& Agustini (2020) advocated the importance of autonomous learning to equip students in order to survive in the $21^{\text {st }}$ century. Apart from developing students' ICT skills, blended learning could assist in developing teachers' digital skills by allowing them to use devices, technological-based tools and resources in its implementation. Consequently, learning was made easy as information can be accessed online anywhere and at any time along with the device to use and good internet connection (Hamouda, 2018; Wahab, Zain \& Yunus, 2018). In regard to face-to-face instruction, time-saving was discovered as an advantage of blended learning (Sorbie, 2015; Oweis, 2018). When teachers were adept at using the blended approach, they could organise their time and manage lesson-related work more effectively. The cost-effectiveness of blended learning was also highlighted, as agreed by Oweis (2018) and Xu et al. (2020).

The achievements recorded in previous blended learning studies demonstrated a clear indicator of the positive effects of blended learning on students' achievement and performance across the four major skills of the English language (Huang, 2019; Challob, Nadzrah \& Hafizah, 2016; Ghazidadeh \& Fatemipour, 2017; Krishnan \& Yunus, 2019; Shih et al., 2015; Said et al., 2013). Students with blended learning experiences showed improvement and developed proficiency at a higher rate as compared to their peers who did not. Furthermore, a boost in students' motivation, participation and engagement during English lessons could be observed (Oweis, 2018; Albiladi \& Alshareef, 2019; Krishnan \&Yunus, 2019; Mustapha et al., 2010). The positive attitudes could be attributed to the integration of technology in teaching and learning, as it steered away from the common classroom environment with added fun and 
interactive elements. Another significant impact of blended learning on English teaching and learning was the increase in engagement and cooperation among students with their peers and teachers. In this respect, Majid and Stapa (2017) stated that blended learning helped to establish positive relationships within the learning space. It is noteworthy to mention that the success of the approach depended on the rapport between students and teachers (Krishnan \& Yunus, 2019; Kintu, Zhu \& Kagambe, 2017).

Blended learning also has a positive effect on the learning environment and experience. The approach allowed for personalisation and students' interests to take place (Krishnan \&Yunus, 2019; Huang, 2019). In other terms, lessons were designed to cater to various learning preferences and styles. Students are able to enjoy the process through technology-mediated learning in blended lessons (Ying \& Yang, 2016). Blended learning also offered the opportunity to have direct experience in using digital devices and tools. Moreover, scaffold learning was promoted through the blended approach, where constant communication and feedback exchanges occured to guide the less proficient students (Majid \& Stapa, 2017). Hence, blended learning can transform the learning atmosphere into a more meaningful experience and conducive environment. Additionally, Wahab et al. (2017) depicted blended learning as a solid example of studentcentred learning that could produce independent and life-long learners, as they were given the prospect of managing their own learning.

\subsection{Challenges Faced by Teachers in Blended Learning Implementation}

The challenges in blended learning implementation provided sound justifications as to why a blended learning endeavour was ineffective and why teachers resisted technology infusion in teaching and learning, leading towards their disinclination to adopt the system. Blended learning required satisfactory technological facilities and resources for online learning. Johnson et al. (2016) elucidated that they still find it difficult to implement modern education technology seamlessly and efficiently, even though teachers typically embraced and appreciated the advantages of educational technologies.

Oweis (2018) investigated the effects of blended learning on tertiary level students' achievement and motivation to learn English. They found several barriers that impeded blended learning implementation. These barriers were observed to have an effect on both learners and teachers. As the use of technological tools was the essence of blended learning, preparation and availability of such resources were vital in order to ensure its smooth operation of the instruction. However, it was discovered that the technical resources were inadequate and internet connectivity was poor, apart from the apparent high maintenance cost of the facilities. Furthermore, teachers commented that blended learning instruction preparation and evaluation took a large amount of time, which posed time constraints to the teachers. Another barrier pinpointed in the study was the concern over plagiarism regarding students' work and the credibility of materials accessed from the Internet.

Conversely, Hamouda (2018) found contrasting challenges to blended learning implementation. The previous research, that considered student-teacher 
interaction as a vital factor to blended learning success, reported that lack of face-to-face interactions and social isolation played a part to impede a good blended learning experience. Due to the limited interaction and communication, students faced difficulty in following instructions given by the teachers apart. From the opinions and feelings towards the blended approach, students had the tendency to cheat in their tasks and were not interested in attending classes, be it face-to-face or online, as they saw it as a waste of time. Students' lack of technological skills and great need for support also contributed to their indifference towards blended learning instruction. Similar to Oweis' (2018) findings, slow connectivity was an obstruction for the ease of blended learning employment. On the other hand, teachers expressed dissatisfaction as there was a decline in teacher's efficiency due to pressure and workload, which led to unorganised blended learning materials.

Parallel to Oweis (2018) and Hamouda (2018), Albiladi and Alshareef (2019) offered a comprehensive explication on the stumbling blocks of blended learning implementation, wherein the digital divide and technology challenges were significant hindrances in blended learning adoption. As clarified by the researchers, the digital divide referred to the ICT available to individuals or societies of the different socioeconomic spectrum. As for teachers, they needed support in terms of technological and pedagogical aspects, including instructional teaching. They also had difficulties in managing materials that were culturally appropriate and familiar for students, setting attainable goals and objectives for students and having insufficient time to conduct the lesson and complete their work. Moreover, outside-of-classroom challenges were a matter for teachers to monitor consistently. The researchers also identified that finding the balance between using new technology innovation and producing cost-effective results was strenuous for teachers. Other challenges consisted of the amount of interaction in both face-to-face and online learning modes, and the types of blended learning activities students participatef in and how their teachers can facilitate them.

In addition, lack of understanding of blended learning hindered blended learning adoption by teachers (Shebansky, 2018). Likewise, the lack of training led to uncertainty and doubts in implementing BL in their instruction. This is in synchronization with Johnson et al.'s (2016) proposition, who suggested that teachers would be incapable of using technologies to their full potential without effective and continuous professional development, which in turn would lead to interminable citation of inadequate professional development as a major hindrance to technology integration. Xu et al. (2020) stated that insufficient highquality English instructors were the cause of reluctance in blended learning adoption. Besides, the search and selection process for relevant materials were considered tedious, while the material development was perceived as timeconsuming. The lack of technical support, as a recurring barrier, was a substantial reason for the hampered adoption of blended learning. It was also deduced that high time commitment impeded the willingness to implement blended learning. 
Hence, this research hoped to gain richer insights into teachers' experiences blended in English language teaching and learning, mainly in rural Sarawak. Such an endeavour would contribute to the body of knowledge as there were limited studies on teacher blended experiences in their teaching and learning of English, especially at the primary school level in Malaysia. Therefore, this research aimed to explore the teachers' experiences and challenges in the implementation of blended learning in primary ESL classrooms by answering the following research questions:

RQ1: What are the teachers' experiences in the implementation of blended learning in the teaching and learning of English?

RQ2: What are the challenges faced by teachers in the implementation of blended learning in primary ESL classrooms?

\section{Methodology}

This research employed a mixed-method design in an explanatory sequential structure. The triangulation and integration of both quantitative and qualitative data analysis were observed throughout the research process to authenticate the gathered data from both means of data collection used in this research work. The conceptual framework for this study was as follows:

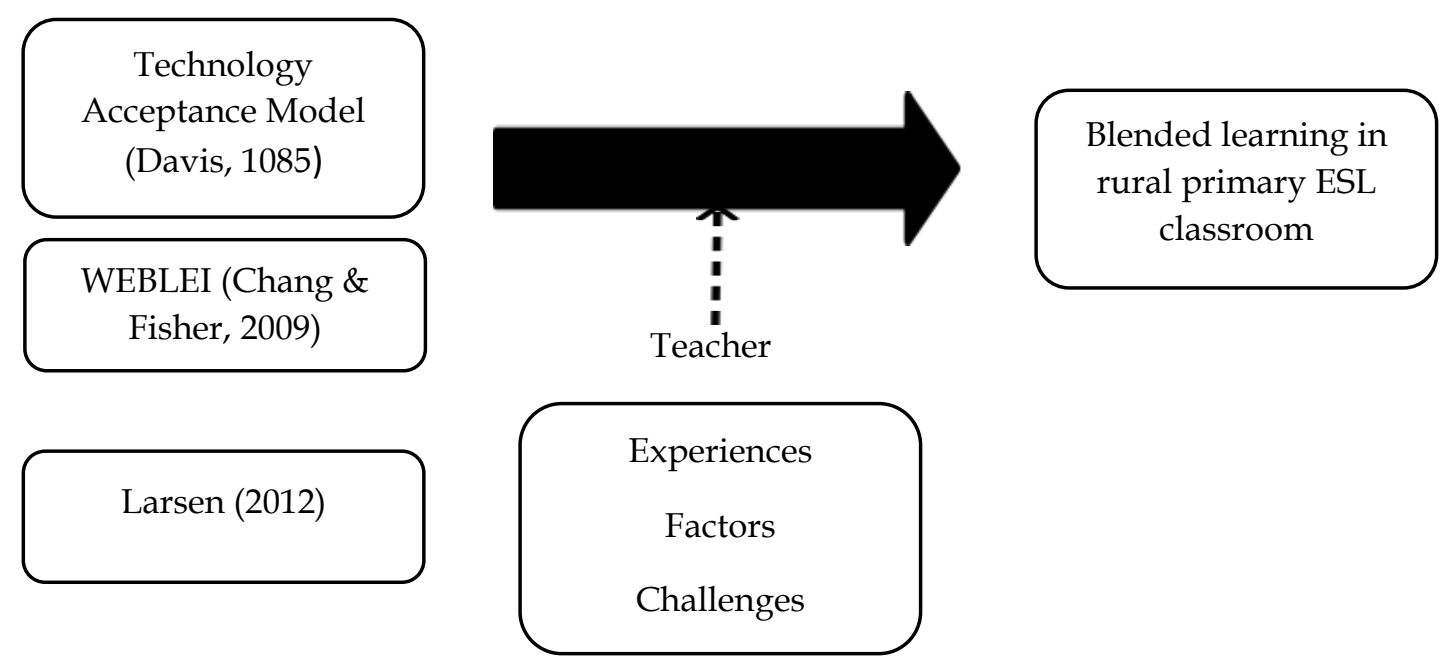

Figure 1. Conceptual Framework

\subsection{Participants}

Purposive sampling was used to select samples of the study from a population of 108 primary school English teachers. It was done based on the Krejcie and Morgan's (1970) table. A total of 86 English teachers teaching in primary schools under the Betong District Education Office (PPD Betong) participated in the survey. Following the COVID-19 outbreak leading to the closures of schools nationwide, teachers had been conducting online classes. They were encouraged by the Pejabat Pendidikan Daerah (PPD) to participate in online workshops, webinars, and meetings with experts and high-performing teachers to up-skill themselves, particularly in managing online and blended learning. This was dependent on the teacher's will and determination to do so. The next step included screening and determining teachers who were willing to participate in 
the interview. Five teachers were interviewed voluntarily, who responded in the survey that they were willing to be interviewed.

\subsection{Research Instruments}

Two research instruments were used to collect data for this research: a questionnaire and interview. The study instrument was replicated from Larsen (2012). The questionnaire was divided into a pre-questionnaire and Web-Based Learning Environment Inventory (WEBLEI) by Chandra and Fisher (2009). The quantitative data were collected using a questionnaire, which was administered via Google Form. The answers to these questions gave insight into formulating questions for the interview. A background questionnaire was mandatory conducted in order to get an accurate and intricate view of teacher participants. In the survey, teachers were asked to fill in a set of preliminary questions to view their teaching experiences and how familiar they were with ICT use and blended learning. Regarding the reliability of WEBLEI, the questionnaire had been tested twice for slightly different applications in Chang and Fisher (2003) and Chandra and Fisher (2009). The Cronbach alpha coefficient for the four scales, namely 'Emancipatory activities', 'Co-participatory activities', 'Qualia' and 'Information structure and design' in the survey ranged from 0.78 to 0.86 , and the fifth scale (facilitation scale) showed a very high level of reliability at $\alpha=.902$ (Larsen, 2012)

An individual semi-structured interview which was adopted from Sorbie (2015) was carried out after collecting data from the survey. The interviews were done using Google Meet and Zoom applications due to meeting restrictions and adaptation to the new normal following the COVID-19 pandemic outbreak. Each interview lasted from 30 to 45 minutes in length, for those interviewees who were comfortable and approved of the time spent. The participants were asked open-ended questions created by the researcher, followed by probes. The broad nature of the interview questions encouraged teachers to expand on their experiences with blended learning and how it had affected them as teachers and their students.

\subsection{Research Procedure}

There were several steps taken by the researcher prior to conducting the research:

Approval was sought from the Malaysian Ministry of Education (MoE) by applying through the Education Research Application System 2.0 (eRAS 2.0).

i. Jabatan Pendidikan Negeri Sarawak (JPNS) was notified of the approval.

ii. The approval was forwarded to PPD Betong to get the final consent by the Head of PPD to proceed.

iii. A letter addressed to school headmasters was issued for them to be notified. The letter contained the Google Form link to the survey and the survey details.

iv. A letter that was addressed to respondents who agreed to be interviewed was issued. The preferred meeting platform and time were discussed and decided between the researcher and respondents. 
The research data collection duration took four weeks, whereby both the survey and interview were to be completed within a two-week time frame. This gave them ample time to complete the survey and prepare themselves for the interview. Once the data were collected, they were analysed quantitatively and qualitatively. Data from the survey were coded and entered as 1 (Strongly Disagree), 2 (Disagree), 3 (Neither Agree nor Disagree), 4 (Agree), and 5 (Strongly Agree) using SPSS. Statistical measurements such as frequency and percentage were determined. The interviews were recorded, transcribed, and tabulated. Transcriptions were compared, allowing for categories and themes to emerge through the six-step thematic coding (Braun \& Clarke, 2006).

\section{Findings}

\subsection{Data from the Survey}

Table 1. Teachers' Experiences in the Implementation of Blended Learning in the Teaching and Learning of English

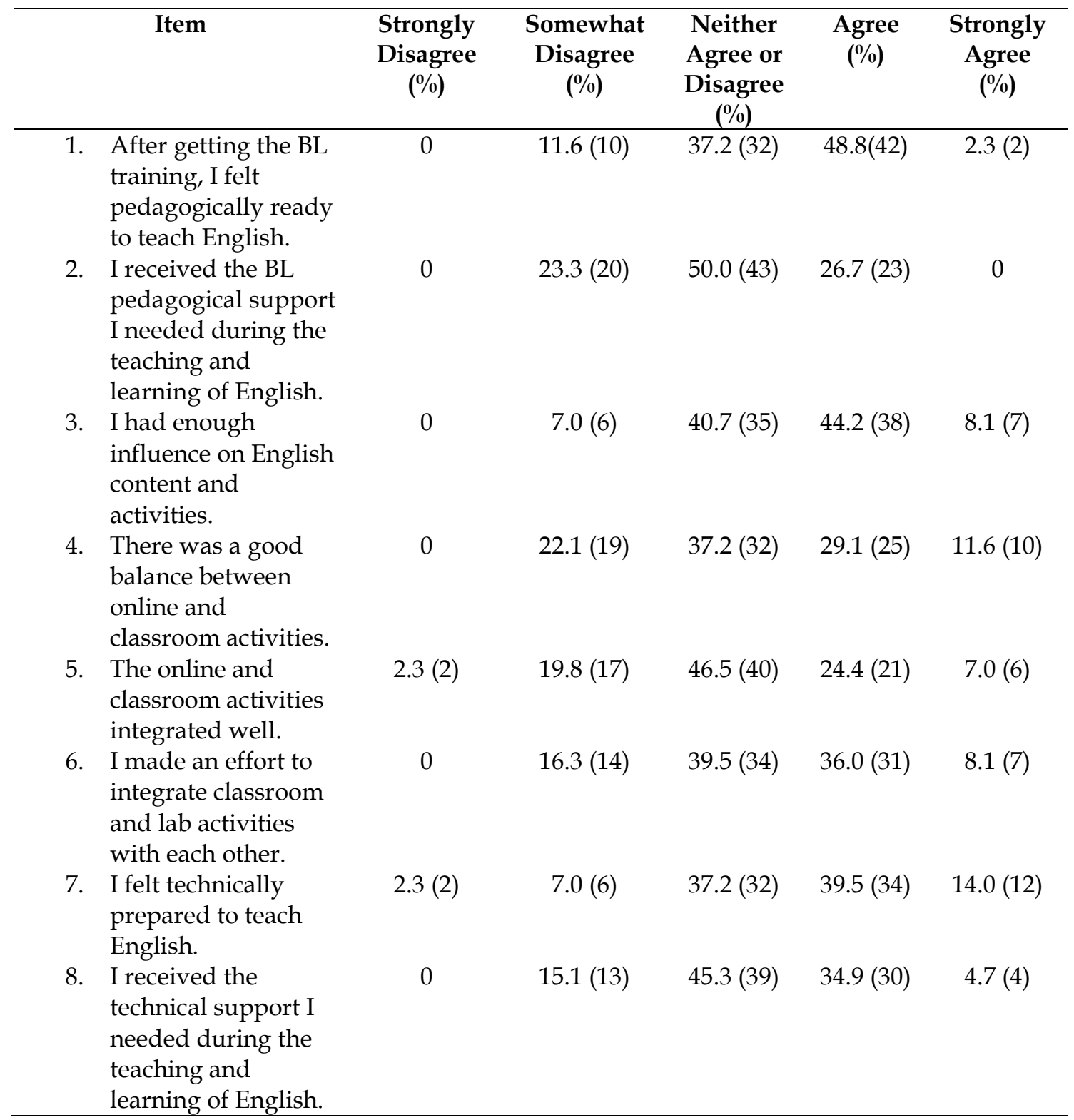




\begin{tabular}{|c|c|c|c|c|c|c|}
\hline 9. & $\begin{array}{l}\text { Using BL did not } \\
\text { make English more } \\
\text { demanding to teach. }\end{array}$ & 0 & $7.0(6)$ & $47.7(41)$ & $36.0(31)$ & $9.3(8)$ \\
\hline 10. & $\begin{array}{l}\text { My teaching style } \\
\text { matches well with } \\
\text { BL. }\end{array}$ & 0 & $14.0(12)$ & $46.5(40)$ & $19.8(17)$ & $19.8(17)$ \\
\hline 11. & $\begin{array}{l}\text { The online activities } \\
\text { worked well. }\end{array}$ & 0 & $23.3(20)$ & $46.5(40)$ & $24.4(21)$ & $5.8(5)$ \\
\hline 12. & $\begin{array}{l}\text { The classroom } \\
\text { activities worked } \\
\text { well. }\end{array}$ & 0 & $7.0(6)$ & $39.5(34)$ & 40.7 (35) & $12.8(11)$ \\
\hline
\end{tabular}

The results can be summarised by saying that neutral responses were given to half of the items in this section of the questionnaire, accounting to six out of 12 items (Items 2, 5, 8, 9, 10, 11). Even so, 6 out of 12 items demonstrated positive feedback from the participants, in which they either agreed or strongly agreed to the statements. All 12 items received negative responses amounting from $2.3 \%$ at a minimum and up to $23.3 \%$ at a maximum, to which their responses were either to disagree or strongly disagree.

Table 2. Challenges in Implementing Blended Learning

\begin{tabular}{|c|c|c|c|c|c|c|}
\hline & Item & $\begin{array}{c}\text { Difficult } \\
(\%)\end{array}$ & $\begin{array}{l}\text { Somewhat } \\
\text { Difficult } \\
(\%)\end{array}$ & $\begin{array}{c}\text { Neither } \\
\text { Easy or } \\
\text { Difficult } \\
(\%) \\
\end{array}$ & $\begin{array}{c}\text { Somewhat } \\
\text { Easy } \\
(\%)\end{array}$ & $\begin{array}{c}\text { Strongly } \\
\text { Easy } \\
(\%)\end{array}$ \\
\hline 13. & $\begin{array}{l}\text { Getting technical } \\
\text { support was... }\end{array}$ & $3.5(3)$ & $22.1(19)$ & $55.8(48)$ & $12.8(11)$ & $5.8(5)$ \\
\hline 14. & $\begin{array}{l}\text { Managing the } \\
\text { online activities } \\
\text { was... }\end{array}$ & $8.1(7)$ & $31.4(27)$ & 33.7 (29) & $36.7(23)$ & 0 \\
\hline 15. & $\begin{array}{l}\text { Managing the } \\
\text { classroom } \\
\text { activities was... }\end{array}$ & 0 & $4.7(4)$ & $37.2(32)$ & $48.8(42)$ & $9.3(8)$ \\
\hline 16. & $\begin{array}{l}\text { Integrating the } \\
\text { online and } \\
\text { classroom } \\
\text { activities was... }\end{array}$ & $2.3(2)$ & $22.1(19)$ & $44.2(38)$ & $29.1(25)$ & $2.3(2)$ \\
\hline
\end{tabular}

Similar to the findings gathered from the previous part of the questionnaire, respondents once again showed mixed responses towards the statements on blended learning challenges. They were mostly neutral towards item 13 and contributed higher percentage to a negative response, indicating that it was difficult to get technical support. This could be attributed to the lack of technical experts amongst them. Item 16 also mostly gained neutral responses, signifying the respondents' doubt towards combining the two modes of classroom activities. They showed a strong positive reaction towards item 15, in which they indicated the simplicity and familiarity in managing classroom activities. There was a clear picture of how the respondents felt about managing the two types of activities. While they reacted positively towards classroom activities, they responded discouragingly towards item 14 (managing online activities). 


\subsection{Data from Semi-Structured Interview}

4.2.1. Teachers' Experiences in the Implementation of Blended Learning in the Teaching and Learning of English

Table 3. Teacher Perceptions

\begin{tabular}{|c|c|c|}
\hline \multirow{5}{*}{ Teacher Perceptions } & Sub-themes & Selected Interview Excerpts \\
\hline & $\begin{array}{c}\text { Development of } \\
\text { teacher's knowledge } \\
\text { and skills }\end{array}$ & $\begin{array}{l}\text { "... allows me to diversify my teaching } \\
\text { strategies...motivate, discipline, self-direct } \\
\text { and manage my pupils' time wisely." } \\
\text { "...allows me to be more technology savvy } \\
\text { by employing an appropriate amount of IT } \\
\text { to improve my teaching practice." } \\
\text { "...deliver contents in various and } \\
\text { interesting ways." } \\
\text { "...helps a lot in enhancing my assessment } \\
\text { style..." } \\
\text { "... select appropriate materials to be used" }\end{array}$ \\
\hline & $\begin{array}{l}\text { Use of technology } \\
\text { and gadgets }\end{array}$ & $\begin{array}{l}\text { "...enjoy learning with the presence of all } \\
\text { those technological tools..." } \\
\text { "...can use laptops in learning..." } \\
\text { "...flexible enough to allow pupils to have } \\
\text { access to internet..." } \\
\text { "Teachers and students are also exposed } \\
\text { with advanced collaboration tools and } \\
\text { technology during online discussions, quick } \\
\text { messages and feedback from teachers and } \\
\text { students." }\end{array}$ \\
\hline & Cost-effectiveness & $\begin{array}{l}\text { "... more cost-effective compared to that of } \\
\text { physical learning" } \\
\text { "...activities can be conducted online which } \\
\text { saves a lot of money" }\end{array}$ \\
\hline & $\begin{array}{l}\text { Easy access to } \\
\text { information }\end{array}$ & $\begin{array}{l}\text { "...could get a lot of examples online...could } \\
\text { access any platform..." } \\
\text { "...high quality online educational websites } \\
\text { and applications..." } \\
\text { "...get the information directly from the } \\
\text { internet and...can immediately share the } \\
\text { ideas" } \\
\text { "...can easily and quickly access everything } \\
\text { as long as we have internet connection" } \\
\text { "Content, materials and references can be } \\
\text { accessed any time." }\end{array}$ \\
\hline
\end{tabular}


There are two main themes discussed in this section, namely (i) Teacher Perceptions and (ii) Successes in Blended Learning. The first recorded sub-theme was the development of teacher's knowledge and skills. The teachers' feedback gave a description of how teachers viewed blended learning implementation as a chance for them to upgrade professionally by broadening their knowledge on the latest teaching pedagogy and methodology, and the necessity to possess commendable ICT skills in order to use technology effectively and smoothly. This could be demonstrated by the responses given by the teachers such as "... allowed me to be more technology savoy by employing an appropriate amount of IT to improve my teaching practice". It was made known during the interviews that blended learning promoted the use of technology and gadgets. Students are inclined to be more engaged and enjoy learning more as technology offered interactive features and colourful visuals, which led to teacher satisfaction upon seeing students enjoying the lessons. On an important note, the interactive nature of the technology allowed for active collaboration and immediate feedback.

Another sub-theme considered was the cost-effectiveness of blended learning. Online learning could help to reduce the cost of material preparation. Instead of spending money to make posters and print worksheets, teachers can opt for the use of technology to deliver their lesson and run their classroom activities. YouTube videos, interactive PowerPoint slides, and online quiz applications such as Quizizz and Kahoot! were among the tools teachers commonly used. A respondent stated that using blended learning is "...more cost-effective compared to that of physical learning". Easy access to information was also a theme revealed from the interviews. There are unlimited resources to English language learning, especially now when technology integration in education continued to grow. An example pertaining to this theme is that "Students can explore information easily on their own".

Table 4. Successes of Blended Learning

\begin{tabular}{|c|c|c|}
\hline \multirow[t]{2}{*}{$\begin{array}{c}\text { Successes of } \\
\text { Blended Learning }\end{array}$} & $\begin{array}{c}\text { Increase in participation, } \\
\text { engagement and } \\
\text { motivation to learn } \\
\text { English }\end{array}$ & $\begin{array}{l}\text { "...more engaged to the assessment..." } \\
\text { "...motivate them to participate actively in } \\
\text { the classroom." } \\
\text { "...paid full attention as much as their } \\
\text { interest towards the learning" } \\
\text { "attract learners' attention and interest } \\
\text { towards their learning" } \\
\text { "...more motivated to learn and compete } \\
\text { healthily..." } \\
\text { "...helps to increase my pupils' motivation } \\
\text { and interest in learning" } \\
\text { "...motivated to learn everyday as they have } \\
\text { fun during the lesson" }\end{array}$ \\
\hline & $\begin{array}{l}\text { Enhancement of } \\
\text { Learning Environment } \\
\text { and Experience }\end{array}$ & $\begin{array}{l}\text { "...allows pupils to enjoy themselves..." } \\
\text { "provides learners more opportunities to } \\
\text { learn..." } \\
\text { "...interesting to learn...not familiar with } \\
\text { all those technology materials and online } \\
\text { media" } \\
\text { "...nature of BL is multisensory and }\end{array}$ \\
\hline
\end{tabular}




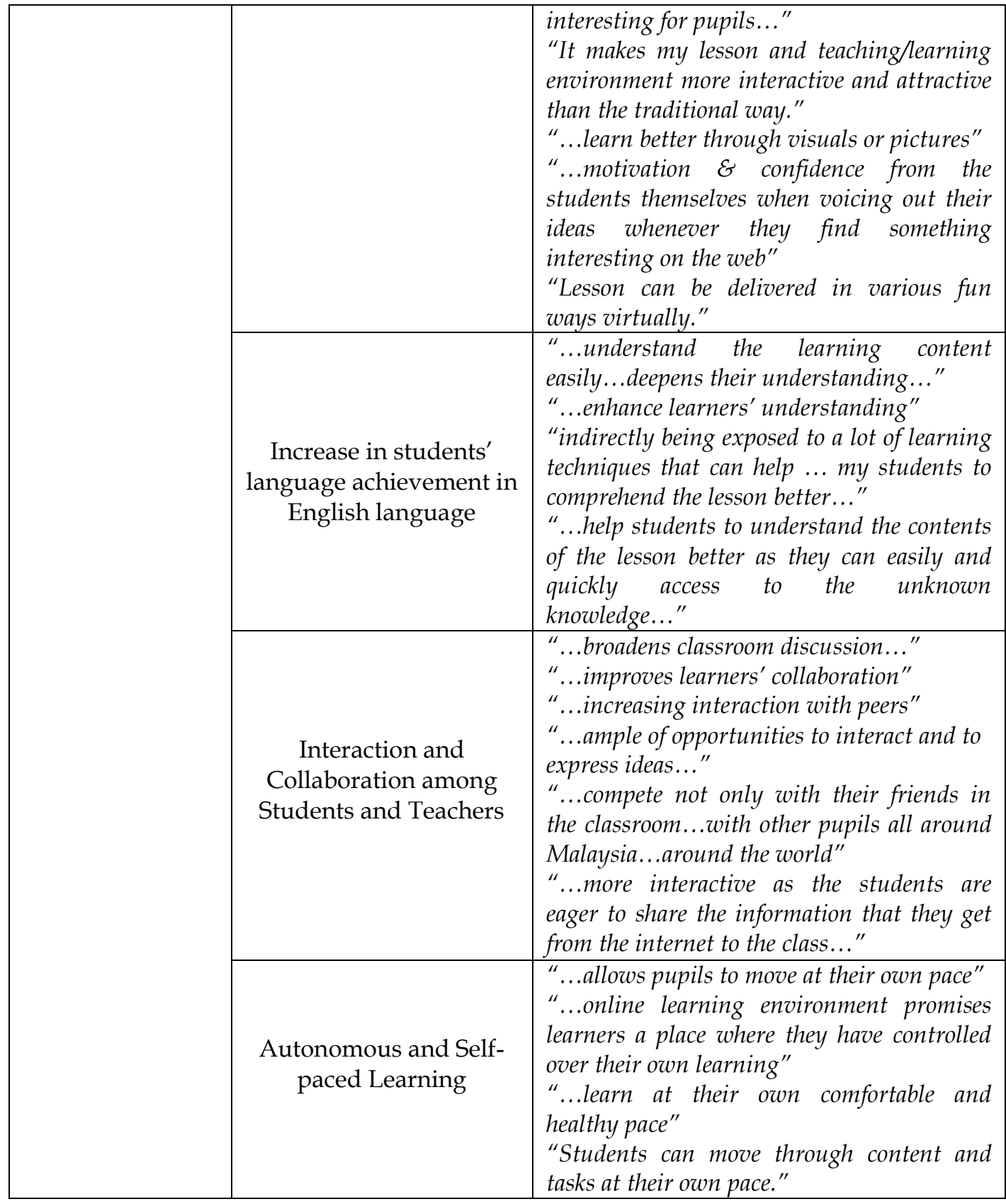

The first theme that surfaced frequently was the increase in participation, engagement and motivation to learn English. Some examples of that illustrated how blended learning could improve students' motivation were: "...more motivated to learn and compete healthily...", and "...helped to increase my pupils' motivation and interest in learning". A respondent also mentioned that her students were"...more engaged to the assessment..." when it was done online. This implied that students were able to concentrate on the task better through online means of assessment as compared to written ones. Also, blended learning can attract students' attention towards learning English as illustrated by the comment that it "attracted learners' attention and interest towards their learning". 
Blended learning can enhance learning environment and experience. Online learning did not only spice up students learning through fun and meaningful media, but also gave them the opportunity to use gadgets and devices. As shared by a respondent, it has been expressed that her students "learn better through visuals or pictures."In parallel, students found security and comfort in their learning environment, leading them to be active and involved during the activities. By way of illustration, the interviewees highlighted that blended learning "provided learners more opportunities to learn..." and "...the nature of BL was multisensory and interesting for pupils...".

Blended learning had a positive effect on students' language achievement in the English language. In this concern, teachers agreed that blended learning could enhance students' understanding in English language learning, in which they stated that students "...understood the learning content easily..., and deepened their understanding...". A teacher added that blended learning led her to discover new methods, strategies and techniques in English language teaching, in which she said that it "indirectly exposed to a lot of learning techniques that can help ... my students to comprehend the lesson better...". Another prominent theme highlighted was autonomous and self-paced learning. Teachers agreed that blended learning encouraged students to learn at their own pace and timing. Some examples of feedback indicating this were the fact that "...online learning environment promised learners a place where they had control over their own learning" and "...learned at their own comfortable and healthy pace." Additionally, "interaction and collaboration among students and teachers" is another theme recognised, whereby blended learning allowed them to remain in contact to discuss and collaborate on their learning tasks. This was congruent with teachers' feedback statements saying that "Blended learning helped to connect teachers with students without physically being present", and "increased interaction with peers".

\subsubsection{Challenges Faced by the Teachers in Implementing Blended Learning in Rural} Primary ESL Classrooms

Four challenges were identified based on teachers' feedback and responses: (i) inadequate facilities and technological constraints, (ii) time consumption, (iii) lack of exposure and skills in ICT use, and (iv) teacher readiness. Table 5 summarized these challenges, while table 6 covered some responses gathered from the interviewees in respect the challenges being highlighted.

Table 5. Challenges Faced by Teachers in the Implementation of Bended Learning

\begin{tabular}{|c|c|}
\hline Challenges & Teacher's Concerns \\
\hline $\begin{array}{l}\text { Inadequate facilities and } \\
\text { technological constraints }\end{array}$ & $\begin{array}{cl}\text { i. } & \text { poor internet connection } \\
\text { ii. } & \text { inadequacy of facilities } \\
\text { iii. } & \text { expensive maintenance fee } \\
\text { iv. } & \text { lack of technical experts } \\
\end{array}$ \\
\hline $\begin{array}{l}\text { Time-consuming and increased } \\
\text { workload }\end{array}$ & $\begin{array}{l}\text { i. need more time to arrange the activities and select } \\
\text { tasks appropriate for the two modes of learning } \\
\text { ii. a decline in teacher's efficiency }\end{array}$ \\
\hline $\begin{array}{l}\text { Lack of exposure and skills } \\
\text { towards the use of ICT }\end{array}$ & $\begin{array}{l}\text { i. inability to perform tasks and participate actively } \\
\text { among students } \\
\text { ii. inability to conduct online classes effectively } \\
\text { among teachers }\end{array}$ \\
\hline
\end{tabular}




\begin{tabular}{|l|l|}
\hline Teacher readiness & i. $\begin{array}{l}\text { inclined to fall back to familiar teaching styles; } \\
\text { ones that they have practised for a long time and } \\
\text { have seen results with }\end{array}$ \\
\hline
\end{tabular}

Table 6. Challenges of Blended Learning with Interviewees' Statements

\begin{tabular}{|c|c|}
\hline Challenges & Selected Interview Excerpts \\
\hline $\begin{array}{l}\text { Inadequate facilities } \\
\text { and technological } \\
\text { constraints }\end{array}$ & $\begin{array}{l}\text { "...have limited numbers of laptop..." } \\
\text { "The school facilities... there are no LCD and computer provided for } \\
\text { every classroom" } \\
\text { "...poor internet connection in my school area...affects the delivery of } \\
\text { the lesson" } \\
\text { "....it depends on the classroom size as well as I've mentioned earlier, } \\
\text { with the lack of devices to use, my students have to share with one } \\
\text { another..." } \\
\text { "...expenses to afford them, technical issues..." } \\
\text { "The school facilities and internet connection" } \\
\text { "...poor internet or technology access..." }\end{array}$ \\
\hline Time consumption & $\begin{array}{l}\text { "Using blended learning in my classroom needs me to prepare more } \\
\text { for the lesson..." } \\
\text { "...need to adapt the content for blended learning... ensure the quality } \\
\text { of the instructional processes...takes a lot of time" } \\
\text { "....in terms of time management,... still struggling..." } \\
\text { "...Time consuming in preparing materials and to get feedback and } \\
\text { outcomes..." } \\
\text { "...Extend timeframe for students to complete tasks given due to low } \\
\text { self-motivation among students..." }\end{array}$ \\
\hline $\begin{array}{l}\text { Lack of exposure and } \\
\text { skills in ICT use }\end{array}$ & $\begin{array}{l}\text { "Pupils were not exposed to technology..." } \\
\text { "...most of them are not familiar with all those technology materials } \\
\text { and online media" } \\
\text { "If every student is provided with good technical aspects and IT } \\
\text { literacy, blended learning can be easily implemented and arouse } \\
\text { students' interest in learning... meaningful impact on learning } \\
\text { experience or they will fall behind due to family economy support and } \\
\text { challenges with management in an online setting." }\end{array}$ \\
\hline $\begin{array}{l}\text { Teacher Readiness } \\
\text { (Preference of } \\
\text { traditional face-to-face } \\
\text { instruction over online } \\
\text { learning) }\end{array}$ & $\begin{array}{l}\text { "...comfortable...enriches learning experiences...suits their current } \\
\text { learning environment... convenient to learners who...hardly to use } \\
\text { technologies throughout their learning" } \\
\text { "...blended learning functions as an 'enhancement tool' you } \\
\text { know...to the traditional face-to-face interaction" } \\
\text { "Teacher may struggle with as the workload is significantly higher } \\
\text { due to number of classes and subjects to be taught...." } \\
\text { "Teacher prefers face-to-face class to make sure the contents of the } \\
\text { lesson are delivered fluently and students achieve the learning } \\
\text { objectives during the live time lesson because not all students have } \\
\text { strong communication and collaboration skills in technology...Direct } \\
\text { supervision...increase motivation" }\end{array}$ \\
\hline
\end{tabular}

The main challenge faced was inadequate facilities and technological constraints. Among the responses received were those related to "limited numbers of laptop..."and "...poor internet connection in my school area" as claimed by the interviewee. The same participant also talked about how the class size affected the smoothness of blended lesson delivery, and this is felt in the following 
excerpts wherein "...it was depended on the classroom size as well as I've mentioned earlier, with the lack of devices to use, my students had to share with one another...". The larger the class size, the more facilities such as laptops were needed for students' individual use. A teacher shared that revisitation of a particular task was bound to happen due to the lack of technological infrastructure and access; as the participant had to "redo the same learning content in a hardcopy (worksheet) for students when it came to poor internet/technology access in order to ensure every student was updated with the content or knowledge." Bearing in mind that the teachers were working in rural schools, and consequently students may not had "...expenses to afford them..." and there may be difficulties in getting experts to resolve "technical issues".

Next, the challenge reported by teachers was that implementing blended learning was time consuming. The responses recorded that teachers "...were required to adapt the content for blended learning...ensure the quality of the instructional processes...took a lot of time" and "...in terms of time management, ...still struggling...". However, two respondents mentioned that blended learning helped to save time in lesson delivery. Planning blended lessons may require a lot of time but teachers perceived to reduce delivery or teacher's presentation time. A response signifying this was that it "...helped save time rather than giving long explanations". Another challenge posed towards students was the lack of exposure and skills in ICT use, as indicated by three respondents. From their point of view; "If every student was provided with good technical aspects and IT literacy, blended learning can be easily implemented and arouse students' interest in learning...meaningful impact on learning experience or they will fall behind due to family economy support and challenges with management in an online setting." This implied that without adequate competency in handling ICT among students, blended learning effectiveness may be affected, and they may find it burdensome, instead of enjoying the learning process.

Furthermore, a challenge experienced by teachers themselves in blended learning was teacher readiness. This was regarding their preference of traditional face-to-face instruction over online learning. A teacher's comments were"...comfortable...enriches learning experiences...suit their current learning environment... convenient to learners who...hardly to use technologies throughout their learning". Hence, this showed that the respondent still believed in the significance of having face-to-face interaction. Another teacher justified that "not all students had strong communication and collaboration skills in technology." The same interviewee stood firm on the perception that "teachers and students in rural areas required the physical presence or face-to-face practices regarding the contents and delivery of lessons to enhance their knowledge and learning behaviour." Based on the respondent's experiences on teaching in rural areas, depending on technology alone would be insufficient and irrelevant. 


\section{Discussion}

\subsection{Teachers' Experiences in the Implementation of Blended Learning}

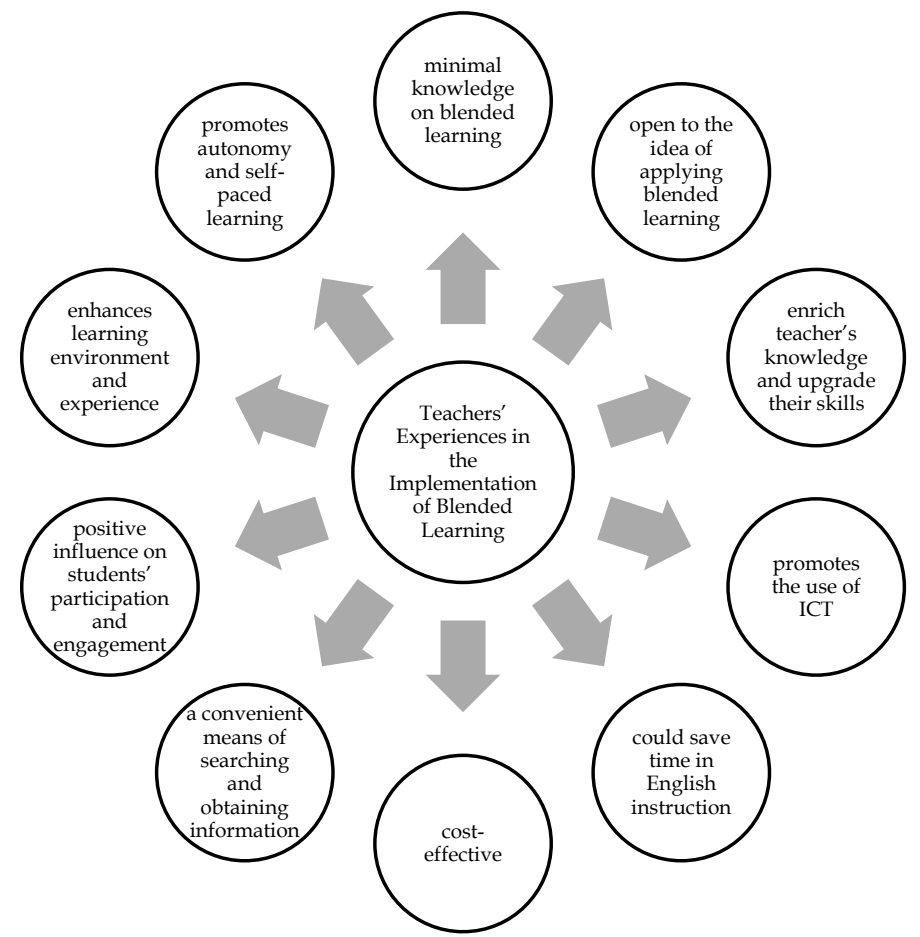

Figure 2. Teacher Experiences in Blended Learning

The major finding obtained from this study was that teachers have minimal knowledge on blended learning. This was illustrated by the mixed reactions teachers had on the application of blended learning in the primary ESL classroom. This could also be attributed to the limited exposure teachers had in blended learning. This finding was in congruence with the study of Ying and Yang (2016), in which academics probably provided vague feedback and expressed the shortcomings of blended learning as an indication of them being unfamiliar with the approach. Despite the lack of knowledge teachers had on blended learning, the answers provided suggested that they were still able to relate it to their teaching practices over the years within the traditional face-toface classroom, and their attempts in using ICT in their teaching and learning practices. On the subject of 'perceived usefulness' (PU) in TAM (Davis, 1989), teachers may be unaware and uninformed about the probability of blended learning in enhancing their teaching practice. This could explain their lack of recognition towards blended learning as a potential strategy to help improve English instruction. The mixed views could also be associated with the limited number of teachers who had never applied blended learning method and those who had never gone for blended learning training. As advocated by Bruggeman et al. (2020), for effective blended learning implementation, a detailed understanding and knowledge of the pedagogical concept was needed.

Focusing on the positive influences blended learning had, the results suggested that teachers were open to the idea of applying blended learning in the teaching and learning of English. Based on the questionnaire's feedback, many 
respondents $(40.7 \%)$ agreed that blended learning offered a good balance between online and classroom activities. In the words of a respondent, "...Blended learning was a style of learning that provided learners more opportunities to learn in two major ways...". The same respondent described the traditional faceto-face interaction as 'convenient to learners' especially in a rural classroom setting where students hardly had the luxury of owning gadgets and online learning as 'enhancement tool' that complements face-to-face instruction. This could be an impetus for teachers to consider the use of blended learning and what affordances it had to offer in their classrooms.

Apart from that, respondents acknowledged that they put in efforts to integrate the two activities (traditional face-to-face and online learning), accounting for a total of $44.1 \%$ of those who agreed to the matter despite having the opinion that combining the two modes were difficult. This contrasts with the concept of 'perceived ease of use' (PEU) in TAM (Davis, 1989), which promoted the tendency of individuals to use a particular system when it was free of effort. In this case, the teachers chose to commit through the complexity of managing two modes of activities. This is in line with the findings of Ibrahim and Nat (2019), in which they discovered that the instructors' motivation to use blended learning was unaffected by their academic workload.

Blended learning had positively impacted the education landscape in various ways. The benefits of blended learning were as follows:

(i) Enriched teacher's knowledge and upgraded their skills in many aspects such as pedagogical knowledge and digital competency,

(ii) Promoted the use of ICT with set of skills mandatory for the future generation to thrive in the future world, thus making it appropriate and relevant for learners to be exposed and trained to use technology competently,

(iii) Saved teaching and learning time as teachers were more organised and prepared for class,

(iv) Cost-effective as there were readily available technological tools such as showing lesson content, using PowerPoint slides, or submitting tasks through email, and/or uploading to a learning management system that did not require the use of paper.

(v) A convenient means of searching and obtaining information,

(vi) Increased students' participation and engagement, whereby it can be observed that students participated more actively and showed more interest during the classroom activities,

(vii) Offered the prospect of communication and collaboration within and beyond the classroom walls where students can build stronger relationships among themselves, and together with their teachers,

(viii) Enhanced learning environment and experience, which in turn helped to improve language achievement, and

Promoted autonomy and self-paced learning as students were encouraged to play a more dominant role in their learning for the very reason that learning may take place according to their pace and ability. 


\section{Conclusion and Future Implications}

To a certain extent, this research's findings indicated that blended learning had a positive influence on the teaching and learning of English in rural primary ESL classrooms. Nonetheless, there were more to discover about blended learning adoption decisions among teachers. Teacher perceptions that implied otherwise were vindicated by the limited exposure and knowledge on blended learning. The challenges which obstruct teachers from implementing the approach should steer the Ministry of Education, academicians, and education personnel to work closely with teachers and other stakeholders (students and parents). This was essential for the intensive and extensive preparation and planning prior to implementing the blended approach in English instruction. School administrators should take the initiative to create an environment that would foster open communication and collaboration, apart from promoting a respectful and supportive atmosphere to encourage teachers to have constructive discussions to address their concerns. It was critical to conduct training to up skill teachers' digital knowledge and skills. With a clear understanding of the blended learning modus operandi, teachers would be more confident and organised in the planning, delivery, and time management. Furthermore, the availability and usability of facilities in schools should be deliberated along with the consideration to expand internet access predominantly in rural areas. The limitations to this study were that the teachers had different academic qualifications, indicating that some did not have an English major, a small sample size, and that generalisation was obscure to experiences of teachers in other geographical locations with disparate demographics. Some suggestions for future work were put forward:

- Diversified learning contexts in Malaysia, focusing on English as a Second Language (ESL) classrooms,

- Examining the effect of blended learning implementation with primary school students with different levels of proficiency and age,

- Blended experience in the teaching and learning of the four major English language skills in a primary ESL classroom,

- Types of blended learning models and appropriate designs for the current CEFR-aligned curriculum in Malaysia,

- Types of digital tools or applications preferred or widely used by teachers to teach English language skills and components.

\section{References}

Albiladi, W. S., \& Alshareef, K. K. (2019). Blended learning in English teaching and learning: A review of the current literature. Journal of Language Teaching and Research, 10(2), 232-238. https://doi.org/10.17507/jltr.1002.03

Al-Azawei, A., Parslow, P., \& Lundquist, K. (2017). Investigating the effect of learning styles in a blended learning system: An extension of the technology acceptance model (TAM). Australasian Journal of Educational Technology, 33(2), 1-23. https://doi.org/10.14742/ajet.2741

Braun, V., \& Clarke, V. (2006). Using thematic analysis in psychology. Qualitative $\begin{array}{llll}\text { Research in } & \text { Psychology, }\end{array}$ https://doi.org/10.1191/1478088706qp063oa

Bruggeman, B., Tondeur, J., Struyven, K., Pynoo, B., Garone, A., \& Vanslambrouck, S. (2020). Experts speaking: Crucial teacher attributes for implementing blended 
learning in higher education. The Internet and Higher Education, 48. https://doi.org/10.1016/j.iheduc.2020.100772

Challob, A. I., Nadzrah, A. B., \& Hafizah, L. (2016). Collaborative blended learning writing environment: Effects on EFL students' writing apprehension and writing performance. English Language Teaching, 9(6), 229-241. https:// doi.org/10.5539/elt.v9n6p229

Chandra, V., \& Fisher, D.L. (2009). Students' perceptions of a blended web-based learning environment. Learning Environment Research, 12, 31-44.

Chang, V., \& Fisher, D. L. (2003). The validation and application of a new learning environment instrument for online learning in higher education. In M. S. Khine \& D. L. Fisher (Eds.), Technology-rich learning environments: A future perspective (pp. 1-20). Singapore: World Scientific Publishing Co. Pte. Ltd.

Cleveland-Innes, M., \& Wilton, D. (2018). Guide to blended learning. Canada: Commonwealth of Learning.

Davis, F. D. (1989). Perceived usefulness, perceived ease of use, and user acceptance of information technology. Management Information Systems Research Centre, 13(3), 319-340. https:/ / doi.org/10.2307/249008

Fitriani, S. S., Weda, S., Samad, I. A., \& Ananda, R. (2021). Genre-based visualisation through an online teaching platform: A strategy to engage with academic texts during the Covid-19 outbreak. XLinguae, 14(1), 270-288. https://doi.org/10.18355/xl.2021.14.01.20

Ghazidadeh, T., \& Fatemipour, H. (2017). The effect of blended learning on EFL learners' reading proficiency. Journal of Language Teaching and Research, 8(3), 606-614. https://doi.org/10.17507/jltr.0803.21

Gough, E., DeJong, D., Grundmeyer, T., \& Baron, M. (2017). K-12 teacher perceptions regarding the flipped classroom model for teaching and learning. Journal of Educational Technology Systems, 45(3), 390-423. https://doi.org/10.1177/0047239516658444

Hamilton, V. R. (2018). Blended learning and second language acquisition in the classroom [Master's thesis, University of Northern Iowa]. https://scholarworks.uni.edu/grp/337

Hamouda, A. (2018). The effect of blended learning on developing Saudi English majors' writing skills. International Journal of English and Education, 7(2), 40-83.

Hariharasudan, A., \& Kot, S. (2018). A scoping review on digital English and education 4.0 for industry 4.0. Social Sciences, 7(11), 1-13. https://doi.org/10.3390/socsci7110227

Huang, Y. (2019). The study on application of blended learning in college English listening and speaking teaching. Paper presented at the $4^{\text {th }}$ Annual International Conference on Education Science and Education Management. https://doi.org/10.12783/dtssehs/esem2019/29758

Ibrahim, M. M., \& Nat, M. (2019). Blended learning motivation model for instructors in higher education institutions. International Journal of Educational Technology in Higher Education, 16(12). https:// doi.org/10.1186/s41239-019-0145-2

Jachin, N., \& Usagawa, T. (2017). Potential impact of blended learning on Teacher Education in Mongolia. Creative Education, 8(9), 1481-1494. https://doi.org/10.4236/ce.2017.89104

Johnson, A. M., Jacovina, M. E., Russell, D. E., \& Soto, C. M. (2016). Challenges and solutions when using technologies in the classroom. In S. A. Crossley \& D. S. McNamara (Eds.), Adaptive educational technologies for literacy instruction (pp. 1329). New York: Taylor \& Francis. https:// doi.org/10.4324/9781315647500-2 
Kim, W. (2007). Towards a definition and methodology for blended learning. In J. Fong \& F. L. Wang (Eds.), Proceedings of Workshop on Blended Learning (pp. 1- 8). Pearson.

Kintu, M. J., Zhu, C., \& Kagambe, E. (2017). Blended learning effectiveness: The relationship between student characteristics, design features and outcomes. International Journal of Educational Technology in Higher Education, 14(7). https:// doi.org/10.1186/s41239-017-0043-4

Krejcie, R. V., \& Morgan, D. W. (1970). Determining sample size for research activities. Educational and Psychological Measurement, 30(3), 607-610. https:// doi.org/10.1177/001316447003000308

Krishnan, P. D., \& Yunus, M. M. (2019). Blended CEFR in enhancing vocabulary among low proficiency students. Arab World English Journal (AWEJ), 5, 141-153. https://doi.org/10.31235/osf.io/ujqma

Larsen, L. J. E. (2012). Teacher and student perspectives on a blended learning intensive English program writing course [Doctoral dissertation, Iowa State University].

Murphy, K. (2019). Duquesne scholarship collection perceptions of blended learning in the high school classroom [Doctoral dissertation, Duquesne University]. https://dsc.duq.edu/etd/1864

Mustapha, S. M., Rahman, N. S. N. A., \& Yunus, M. M. (2010). Factors influencing classroom participation: A case study of Malaysian undergraduate students. Procedia - Social and Behavioral Sciences, 9, 1079-1084. https://doi.org/10.1016/j.sbspro.2010.12.289

Oweis, T. I. (2018). Effects of using a blended learning method on students' achievement and motivation to learn English in Jordan: A pilot case study. Hindawi, 2018, 1-7. https:// doi.org/10.1155/2018/7425924

Padmadewi, N. N., Artini, L. P., \& Agustini, D. A. E. (2020). Promoting autonomous learning and $21^{\text {st }}$ century skills of English education students through empowering their pedagogical skills. Proceedings of the $4^{\text {th }}$ Asian Education Symposium (AES 2019): Advances in Social Science, Education and Humanities Research. https://doi.org/10.2991/assehr.k.200513.024

Polushkina, T. A., \& Tareva, E. G. (2021). Developing L2 prosodic competence online: Implications of the emergency remote teaching. XLinguae, 14(1), 38-48. https://doi.org/10.18355/x1.2021.14.01.03

Raymond, S. (2019). High tchool Teacher perceptions of blended learning [Doctoral Dissertation, Walden University]. https://scholarworks.waldenu.edu/dissertations/7725

Razali, N. N. F. M. (2016). The importance and efforts in using technology to improve language teaching and learning and the teacher's readiness for integrating ICT in the classroom in Malaysian education. Journal of Education and Social Sciences, 5(2), 227-230.

Said, N. E. M., Yunus, M. M., Doring, L. K., Alfian, A., Aqilah, F., \& Li, L. K. S. (2013). Blogging to enhance writing skills: A survey of students' perception and attitude. Asian Social Science, 9(16), 95-101. https://doi.org/10.5539/ass.v9n16p95

Shebansky, W. (2018). Blended learning adoption in an ESL context: Obstacles and guidelines. TESL Canada Journal, 35(1), 52-77. https:// doi.org/10.18806/tesl.v35i1.1284

Shih, R. C., Lee, C., \& Cheng, T. (2015). Effects of English spelling learning experience through a mobile line app for college students. Procedia - Social and Behavioral Sciences, 174, 2634-2638. https://doi.org/10.1016/j.sbspro.2015.01.945

Sorbie, J. (2015). Exploring teacher perceptions of blended learning (Doctoral Dissertation, 
Walden University] https:// scholarworks.waldenu.edu/dissertations/1866

Wahab, N. A., Zain, A. M., \& Yunus, M. M. (2018). Exploring the blended learning experience among $21^{\text {st }}$ century language learners. Journal of Language and Communication, 5(1), 136-149.

Xu, D., Glick, D., Rodriguez, F., Cung, B., Li, Q., \& Warschauer, M. (2019). Does blended instruction enhance English language learning in developing countries? Evidence from Mexico. British Journal of Educational Technology, 51(1), 211-227. https://doi.org/10.1111/bjet.12797

Ying, A. N. L., \& Yang, I. (2016). Academics and learners' perceptions on blended learning as a strategic initiative to improve student learning experience [Conference presentation]. 9th International Unimas Stem Engineering Conference (ENCON 2016) "Innovative Solutions for Engineering and Technology Challenges, MATEC Web Conf (Vol. 87). https:/ / doi.org/10.1051/matecconf/20178704005 